\title{
Hemoglobin E syndromes in Pakistani population
}

\author{
Bushra Moiz, Mashhooda Rasool Hashmi, Amna Nasir, Anila Rashid and Tariq Moatter
}

\begin{abstract}
Background: Hemoglobin $E$ is an important hemoglobin variant with a worldwide distribution. A number of hemoglobinopathies have been reported from Pakistan. However a comprehensive description of hemoglobin $E$ syndromes for the country was never made. This study aimed to describe various hemoglobin E disorders based on hematological parameters and chromatography. The sub-aim was to characterize hemoglobin $E$ at molecular level.

Methods: This was a hospital based study conducted prospectively for a period of one year extending from January 1 to December 31, 2008. EDTA blood samples were analyzed for completed blood counts and hemoglobin variants through automated hematology analyzer and Bio-Rad beta thalassaemia short program respectively. Six samples were randomly selected to characterize HbE at molecular level through RFLP-PCR utilizing Mn/l restriction enzyme.

Results: During the study period, 11403 chromatograms were analyzed and $\mathrm{Hb}$ E was detected in 41 (or 0.36\%) samples. Different hemoglobin E syndromes identified were HbEA ( $n=20$ or $49 \%$ ), HbE/ $\beta$-thalassemia ( $n=14$ or $34 \%), \mathrm{HbEE}(\mathrm{n}=6$ or $15 \%$ ) and $\mathrm{HbE} / \mathrm{HbS}(\mathrm{n}=1$ or $2 \%$ ). Compound heterozygosity for HbE and beta thalassaemia was found to be the most severely affected phenotype. RFLP-PCR utilizing Mnll successfully characterized HbE at molecular level in six randomly selected samples.

Conclusions: Various HbE phenotypes are prevalent in Pakistan with HbEA and HbE/ $\beta$ thalassaemia representing the most common syndromes. Chromatography cannot only successfully identify hemoglobin E but also assist in further characterization into its phenotype including compound heterozygosity. Definitive diagnosis of HbE can easily be achieved through RFLP-PCR.
\end{abstract}

Keywords: Hemoglobin E, Hemoglobin variants, Pakistan

\section{Background}

Hemoglobin $\mathrm{E}$ is an important and common $\beta$-globin chain variant resulting from substitution of glutamine by lysine at codon 26 of $\beta$-globin gene $\left(\infty 2 \beta 2^{26 G l u \rightarrow \text { Lys }}\right)$. Since its first description by Chernoff and his colleagues in 1954 [1], HbE was increasingly reported from several parts of the world. Hb E confers a survival advantage against Plasmodium falciparum and could be the logical explanation for its high global prevalence [2]. It is the most prevalent abnormal hemoglobin in South East Asia with its frequency approaching $60 \%$ in Northeast regions of Thailand [3,4], Laos and Cambodia [5]. Significant numbers were reported from other Asian countries such as Sri Lanka [6], North Eastern India [7], Bangladesh

\footnotetext{
* Correspondence: bushra.moiz@aku.edu

Department of Pathology and Microbiology, The Aga Khan University Hospital, Stadium road, Karachi 74800, Pakistan
}

[8], Nepal [6], Vietnam [9] and Malaysia [10]. Additionally, population transmigration led to its emergence in United States [11] and Canada [5].

$\mathrm{Hb} \mathrm{E}$ occurs both in homozygous (EE) and heterozygous (EA or E trait) states and may co-inherits with alpha [12] and beta thalassaemia [13], $\mathrm{HbS}, \mathrm{HbC}$ and other hemoglobin variants [6]. Hb EE and E trait are mild disorders and are associated with either mild or no anemia. In contrast, $\mathrm{HbE} / \mathrm{beta}$ thalassaemia displayed a remarkable variability in its clinical severity varying from mildly asymptomatic state to a severe transfusion dependent anemia [14]. HbE/HbS results in a sickle cell disorder similar to sickle/beta + thalassaemia [14].

It is important to diagnose $\mathrm{Hb} \mathrm{E}$ disorders correctly as the clinical course is variable for various phenotypes and would modify the management. A cost effective and simple combination of hemoglobin instability and osmotic fragility tests was devised for detection of $\mathrm{Hb} \mathrm{E}$ in
C Biomed Central

(c) 2012 Moiz et al; licensee BioMed Central Ltd. This is an Open Access article distributed under the terms of the Creative Commons Attribution License (http://creativecommons.org/licenses/by/2.0), which permits unrestricted use, distribution, and reproduction in any medium, provided the original work is properly cited. 
low socio-economic countries [15] Other methods include hemoglobin electrophoresis where $\mathrm{Hb} \mathrm{E}$ runs with the same speed as $\mathrm{Hb} \mathrm{A}_{2}$ on alkaline $\mathrm{pH}$ requiring subsequent identification on acidic $\mathrm{pH}$. On high performance liquid chromatography (HPLC), $\mathrm{Hb} \mathrm{E}$ has the same retention time as $\mathrm{HbA}_{2}$ [16] but is identified because of its quantity which is substantial in comparison to $\mathrm{HbA}_{2}$. Ultimate diagnosis of this variant rests on molecular analysis. RFLP-PCR [17], DNA sequencing and allelic discrimination analysis [18] are successfully used for molecular characterization of hemoglobin E.

Situated in South Asia, Pakistan is a home to 180 million people. Various hemoglobinopathies have been reported from this country [19] including alpha [20] and beta thalassaemia [21,22], sickle cell disorders [23], Hb D [24,25], Hb Q [26] and other rare variants [27]. Sporadic cases of $\mathrm{HbE}$ have been reported from Pakistanis living in United Kingdom [6,28] but the information regarding $\mathrm{HbE}$ for the country remains fragmentary hitherto. Since Pakistan showed a high incidence of beta thalassaemia major [22,29], high estimates for $\mathrm{HbE} / \beta$ thalassaemia syndromes were expected. Further to this credence, there was a need to characterize $\mathrm{HbE}$ in the large and diverse population of the country in order to ensure optimal patient management. The present hospital based study was focused on the identification of $\mathrm{Hb}$ E through HPLC and on stratification of its various phenotypes based on hematological parameters. No attempt was made to analyze other hemoglobinopathies as a number of previous studies had already addressed this issue. The study also aimed for molecular characterization of $\mathrm{HbE}$.

\section{Methods}

\section{Sample collection}

We prospectively analyzed blood samples during one year from January 1 to December31, 2008 in the clinical laboratory of The Aga Khan University, Pakistan. The patients were referred by various physicians from within and outside the hospital for the work up of anemia, antenatal and pre-marital screening. The laboratory served as a referral laboratory for the country and samples were obtained from 94 blood collection centers within the city and 82 similar centers from the entire country. Clinical details were assessed based on information provided by the requesting physicians.

\section{Complete blood counts and chromatographic analysis of hemoglobin variants}

Briefly, we collected five milliliters of blood from each patient in ethylene di-amine tetra acetate micro cuvettes (BD, Becton Dickinson and Company, New Jersey, USA). The samples were received cooled at $4^{\circ} \mathrm{C}$ by fast transportation in our lab and were analyzed within $24 \mathrm{~h}$.
Hemogram was performed on each sample by Coulter Gen-S (Coulter Electronics, Fullerton, CA, USA), and peripheral film stained with Leishman's stain was examined by experienced technologists and hematologists.

We used the Bio-Rad Variant Classic $\beta$ Thalassaemia Short program (Bio-Rad Laboratories Inc. Hercules, CA, and USA) for the hemoglobin quantification. This automated system utilizes the principle of cation exchange HPLC with detection at double wavelength (415 and $690 \mathrm{~nm}$ ). The instrument is user friendly and analyzed each sample for a period of 5-6 min., with various positively charged hemoglobin molecules eluting at different times depending on their affinity for anion-coated resin columns. We use a retention time (RT) of 3.65 to 3.7 min to identify $\mathrm{Hb} \mathrm{E}+\mathrm{Hb} \mathrm{A}_{2}$ as the two co-elute in the same $\mathrm{A}_{2}$ window [16].

\section{Molecular analysis}

In mutational analysis, we prospectively selected 6 samples which were screened as $\mathrm{Hb} \mathrm{E}$ trait $(\mathrm{n}=2)$ and $\mathrm{Hb}$ E/beta thalassaemia $(n=4)$ on HPLC. Total genomic DNA was isolated from peripheral white cells according to manufacturer's instructions using Wizard ${ }^{\mathbb{R}}$ Genomic DNA Purification kit (Promega USA Cat No: A1125). RFLP-PCR based approach was used for detecting $\beta 26$ $\mathrm{G} \rightarrow$ A mutation utilizing enzyme $M n l \mathrm{I}$ [30]. Hb E mutation destroys a cleavage site for $M n l \mathrm{I}$ which cleaves DNA at the sequence 3'-GAGG-5' [31]. The schematic representation of beta gene with primers and sequence amplified along with cut base pair sizes are detailed in Figure 1. PCR amplification was performed using $1 \mu \mathrm{g}$ of genomic DNA in $25 \mu \mathrm{l}$ reaction optimized by using the following concentrations: $5 \times$ buffer $5 \mu \mathrm{l}, \mathrm{MgCl} 21.5$

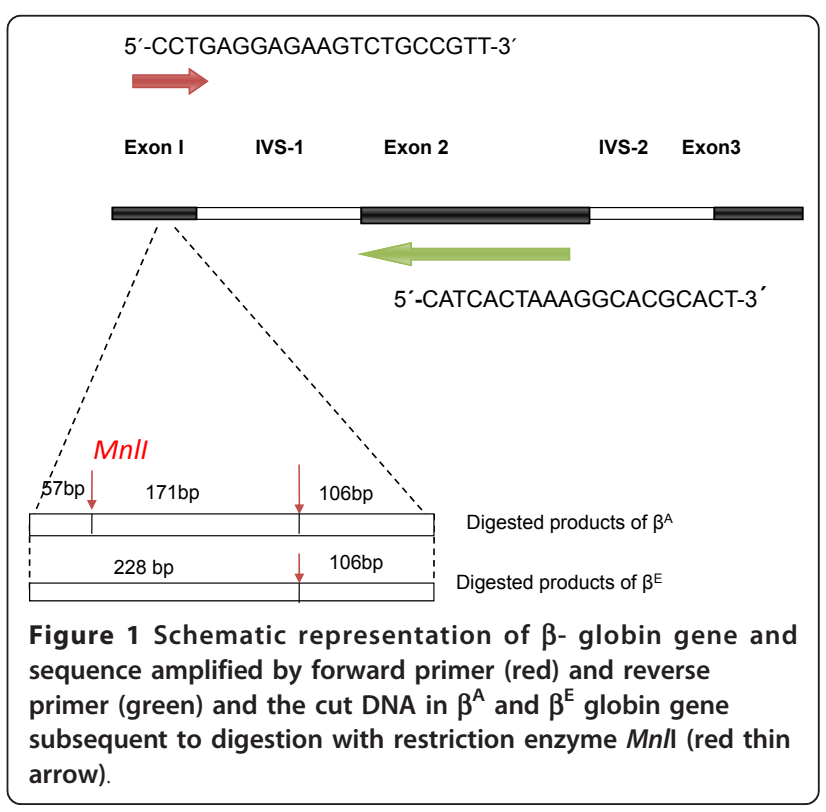


$\mu \mathrm{l}$, DNTP $1 \mu \mathrm{l}$, each primer $0.5 \mu \mathrm{l}$, Taq polymerase $0.5 \mathrm{U}$ reconstituted with $14 \mu \mathrm{l}$ of water. Eppendorf ${ }^{\circledR}$ Master Cycler gradient (Germany) using annealing temperatures calculated according to Tm of primer pairs run at 34 cycles with a further $7 \mathrm{~min}$ extension at $72^{\circ} \mathrm{C}$. Amplified products were digested with 5 units of $M n l \mathrm{I}$ and separated through electrophoresis on 1.5\% agarose gel. These were visualized under UV light after ethidium bromide staining.

\section{Statistical analysis}

The data was entered into SPSS version 16(SPSS Inc., Chicago, IL, USA) to compute descriptive data. Various hemoglobin $\mathrm{E}$ phenotypes were identified with respect to hemoglobin, red cell indices and hemoglobin variants $\left(\mathrm{HbE}+\mathrm{HbA}_{2}, \mathrm{Hb} \mathrm{F}, \mathrm{HbA}\right.$ or any other variant) as described in literature $[6,14,18]$.

\section{Ethical issues}

The study was approved by institutional ethical review committee of The Aga Khan University (ERC approval \#1600-P80-ERC-2010). The retrieved computerized data from laboratory was re-coded to maintain anonymity. The samples were collected from patients after their informed consent.

\section{Results}

We reviewed 11403 chromatograms in the year 2008 identifying 1944 (17\%) samples with hemoglobin variants. The hemoglobinopathies detected were as follows: $\beta$-thalassaemia trait, $\beta$-thalassaemia major, $\mathrm{Hb} \mathrm{S}$ disorders, $\mathrm{Hb} \mathrm{D}$ and $\mathrm{Hb} \mathrm{Q}$ in 1174 (60\%), 274(14\%),246 (13\%),193 (10\%) and 7(0.4\%) samples respectively. One case of $\mathrm{Hb} \mathrm{C}$ and $\mathrm{Hb} \mathrm{H}$ each were identified. Another 48 cases $(2 \%$ of abnormal variants or $0.4 \%$ of total analyzed samples) were observed having the retention time of 3.65 to $3.7 \mathrm{~min}$ and were preliminary labeled as Hemoglobin E. There were seven samples with 38-48\% of abnormal hemoglobin where the possibility of $\mathrm{Hb} \mathrm{D}$ Iran could not be excluded. These were excluded from final analysis leaving a total of 41 cases for evaluation of Hb E.

\section{Subjects characteristics}

The mean age $( \pm$ SD) was 13.6 years $( \pm 11.3)$ ranging from 4 months to 38 years. There were 23 males and 18 females. Clinical details were available for some of the patients and hence were discussed where obtainable.

\section{Hematological analysis}

\section{Hb E Trait}

This constituted the largest diagnosed group comprising of $48.8 \%(n=20)$. There were 10 males and an equal number of females with a median age of $14.0 \pm$
12.8 years. Thirteen children and seven adults were diagnosed. Hemoglobin E ranged from 16.4 to $30.6 \%$ (mean $\pm \mathrm{SD} ; 25.9 \pm 4.3$ ). Six patients showed high $\mathrm{HbF}$ ranging from 4.1 to $8.6 \%$. Only six (30\%) subjects (four females and two males) had hemoglobin within reference range. Remaining 14 patients had lower mean hemoglobin, MCV and MCH $[8.6 \pm 2.4 \mathrm{~g} / \mathrm{dl}, 65.5 \pm$ $9.1 \mathrm{fl}$ and $21.2 \pm 3.4 \mathrm{pg}$ respectively] as well as hypochromic microcytic red cells with anisocytosis. Three patients had severe anemia with hemoglobin less than $7.0 \mathrm{~g} / \mathrm{dl}$.

\section{2. $\beta$-thalassaemia/HbE}

Fourteen (34\%) cases (10 females and 4 males with median age of $9.3 \pm 7.3$ years) were diagnosed as compound heterozygotes for $\mathrm{HbE}$ and $\beta$ - thalassaemia. None of the patient in this group showed hemoglobin above $8 \mathrm{~g} / \mathrm{dl}$. The mean MCV and $\mathrm{MCH}$ were $68.1 \pm 9.3 \mathrm{fl}$ and 21.0 \pm 3.3 pg respectively. $\mathrm{Hb} \mathrm{F}$ was high in all patients ranging from 16.3 to $64.7 \%$ while $\mathrm{HbE}$ was variable from 11.6 to $65.3 \%$. Peripheral film review showed hypochromic microcytic red cells in all cases with nucleated red cells in twelve cases. No attempt was made to differentiate $\mathrm{HbE} / \beta^{\circ}$ and $\mathrm{HbE} / \beta+$ as samples were not analysed for $\beta$-thalassemia mutations.

\section{HbEE Homozygosity}

Hemoglobin EE disorder was observed in six (14.6\%) patients (four males and two females with median age of $24 \pm 8$ years). The criteria for diagnosis was a high $\mathrm{HbE}(>78 \%)$ and a low $\operatorname{HbF}(<3 \%)$. The females $(\mathrm{n}=$ 4) had hemoglobin in the range of 9.6 to $10.6 \mathrm{~g} / \mathrm{dl}$. Two males aged four and 25 years had hemoglobin of $7.6 \mathrm{~g} /$ $\mathrm{dl}$ each. All subjects had hypochromic and microcytic red cell indices. Only one patient had high $\mathrm{HbF}(8.5 \%)$ then the set criteria. He was a 25 year old male with hemoglobin of $7.6 \mathrm{~g} / \mathrm{dl}$. The possibility of co-existing $\alpha$ thalassaemia cannot be excluded in this patient.

\section{4. $\mathrm{HbE} / \mathrm{Hb} \mathrm{S}$}

Compound heterozygosity for $\mathrm{HbE}$ and $\mathrm{HbS}$ was seen in one case. This patient presented at the age of two years with anemia and splenomegaly and had received only one transfusion in the past two years. Hematological parameters are given in Table 1.

\section{Molecular analysis}

Results of DNA analysis of six samples before and after $\mathrm{Mnl \textrm {I }}$ digestion are shown in Figure 2. The amplification of gene produces a 334 bp product in wild and mutant types (figure not shown). Subsequent to digestion three fragments of 57, 106 and 171 bp were observed in wild type and two fragments 106 and 228 bp products were seen in mutant type. Two heterozygous subjects $\left(\beta^{\mathrm{A}} / \beta^{\mathrm{E}}\right)$ and four with compound heterozygosity for $\beta$ thalassae$\mathrm{mia} / \mathrm{HbE}$ showed four fragments of 57, 106, 171 and $228 \mathrm{bp}$. 
Table 1 Hematological features of various hemoglobin E phenotypes $(n=41)$

\begin{tabular}{|c|c|c|c|c|c|c|c|c|}
\hline Phenotype & $\mathrm{n}$ & $\mathrm{Hb}(\mathrm{g} / \mathrm{dl})$ & MCV (fl) & $\mathrm{MCH}(\mathrm{pg})$ & $\mathrm{HbA}(\%)$ & $\mathrm{HbE}+\mathrm{A} 2$ (\%) & $\mathrm{Hb}$ (F \%) & Others (\%) \\
\hline $\mathrm{EE}$ & 6 & $8.8 \pm 1.6$ & $56.9 \pm 4.1$ & $17.4 \pm 1.8$ & 0 & $81.7 \pm 1.9$ & $2.4 \pm 3.3$ & - \\
\hline EA & 20 & $9.7 \pm 2.6$ & $67.3 \pm 8.1$ & $21.9 \pm 3.1$ & $72.3 \pm 4.3$ & $25.9 \pm 4.3$ & $2.1 \pm 3.4$ & - \\
\hline$E / \beta$-thalassaemia & 14 & $5.0 \pm 1.8$ & $68.1 \pm 9.3$ & $21.0 \pm 3.3$ & $19.9 \pm 16.0$ & $43.7 \pm 16.3$ & $36.3 \pm 13.8$ & - \\
\hline$E / S$ & 1 & 7.6 & 67.6 & 20.4 & 0 & 11.8 & 19.3 & $\mathrm{HbS}=68.9$ \\
\hline All cases & 41 & $7.9 \pm 3.0$ & $66.0 \pm 8.7$ & $20.9 \pm 3.3$ & $42.1 \pm 32.1$ & $39.8 \pm 21.9$ & $14.2 \pm 18.3$ & \\
\hline
\end{tabular}

\section{Discussion}

$\mathrm{Hb} \mathrm{E}$ was detected in $0.4 \%$ of our samples. Our clinical lab receives samples from the entire country hence the population was well represented in the study. Since this was a hospital based study, the observed frequency might be an overestimation of the true incidence in general population. However, our intention was to identify and report $\mathrm{HbE}$ in Pakistani population and this study served our purpose. Heterozygous AE represented the commonest phenotype followed by $\beta$ - thalassaemia/Hb in Pakistan. Various HbE phenotypes were differentiated through cation exchange chromatographic analysis and successfully characterized at molecular level. For diagnosis of $\mathrm{HbE}$, a retention time of 3.65-3.7 min was used. Besides $\mathrm{HbE}$, several hemoglobin variants $\left[\mathrm{HbA}_{2}, \mathrm{Hb}\right.$ Lepore, Hb D-Iran, HbG-Honolulu, Hb Korle-Bu] elute in the $\mathrm{A}_{2}$ window(RT: 3.30-3.90) [16]. These can be successfully differentiated on the basis of variance in their quantities and RT [16]. Hence authors believe that $\mathrm{HbE}$ was correctly identified as supported by the molecular studies.

Clinically $\mathrm{HbE}$ is a mild type of disorder both in homozygous and heterozygous states therefore $\mathrm{Hb} \mathrm{E}$

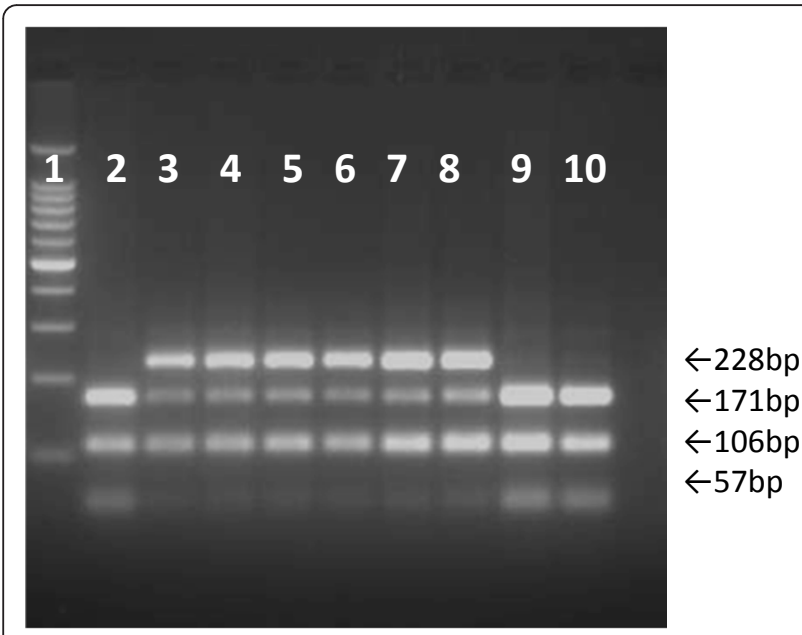

Figure 2 Cut DNA subsequent to digestion with Mnll. M = Molecular marker of 100 bp, lanes 1, 8, $9=$ normal subjects; lane 2 and 3 = subjects heterozygous for $\mathrm{HbE}\left(\beta^{\mathrm{A}} / \beta^{\mathrm{E}}\right)$; lanes $4-7=$ subjects compound heterozygous for $\mathrm{HbE}$ and beta thalassaemia; lane $10=$ blank. individuals are minimally anemic and asymptomatic [6]. However, co-inheritance of hemoglobin $\mathrm{E}$ and beta thalassaemia trait results in $\beta$ - thalassaemia/HbE disease having variable phenotypes ranging from transfusion dependence to a complete absence of symptoms [28]. This inconsistent expression is attributed to $\mathrm{HbE}$ instability during fever and oxidative stress leading to fall in hemoglobin concentration [32]. It is the commonest form of severe thalassaemia in the world and is most prevalent in South Asia. We observed that our subjects with $\beta$ - thalassaemia/HbE were mainly young children (aged four months to 13 years) who presented with severe hypochromic and microcytic anemia having target cells, basophilic stippling, fragmented red cells and nucleated red cells. The young age at presentation reflects the severity of anemia and hence early consultation. This was the most severely affected phenotype observed and the patients in this group demonstrated very low levels of hemoglobin. Since, $\beta$-thalassaemia is widely prevalent in Pakistan with a carrier rate of $5 \%$ [22]; this combination of $\mathrm{HbE}$ and $\beta$-thalassaemia was not unexpected. We could not differentiate $\mathrm{HbE} / \beta^{\circ}$ from $\mathrm{HbE} / \beta+$ as samples were not analyzed for $\beta$-thalassemia mutations. However, Rees DC studied 45 patients with $\beta$ - thalassaemia/ $\mathrm{HbE}$ and showed that $\mathrm{HbE} / \mathrm{HbF}$ ratio was significantly higher (3.1) in patients with regular transfusions in contrast to 1.8 in un-transfused patients. This reflected the relative reduction in $\gamma$-globin chain synthesis subsequent to blood transfusions. $\mathrm{HbE} / \mathrm{HbF}$ ratio in 12 of the patients in our study ranged from 0.27 to 2.0 (mean $\pm 1 \mathrm{SD} ; 1.4 \pm 0.98$ ) showing infrequent blood transfusions. Two patients had higher ratios 2.65 and 4.0 but both of them were on regular blood transfusions.

Subjects with hemoglobin E trait were mostly young adults and the reasons for their testing were extended family screening or investigation of hypochromic microcytic red cells on routine CBC. Females were evaluated as a work up of their antenatal screening. Contrary to usual finding of mild or no anemia in hemoglobin AE, 14 subjects $(70 \%)$ presented with hypochromic and microcytic anemia including three patients with severe anemia $(<7 \mathrm{~g} / \mathrm{dl})$. Two possible explanations were either the presence of iron deficiency anemia or concomitant occurrence of $\alpha$-thalassaemia. Iron deficiency is 
rampant in Pakistan [33-35] while $\alpha$ - thalassaemia has a reported prevalence rate of over $2 \%$ in the country [20]. In 1987, Katsanis E et al. studied 33 children with $\mathrm{HbE}$ trait and observed co-existing anemia in $62 \%$ of them having substantially lower hemoglobin levels and $\mathrm{HbE} \%$ than expected [5]. Unfortunately, iron studies and $\alpha-$ thalassaemia tests were not available for our subjects. Usually the carrier state demonstrates $20-30 \%$ of hemoglobin $\mathrm{E}$ but we observed a lower range of $16-19 \%$ in three cases. Authors believed that concomitant iron deficiency or alpha thalassemia resulted in lowering of $\mathrm{Hb} \mathrm{E}[6]$.

Six cases with homozygous $E$ were observed in the study. Our criteria of diagnosis were $\mathrm{HbE}>75 \%$ and < $3 \%$ hemoglobin F. It has been argued that HbEE and $\mathrm{HbE} /$ beta thalassaemia are overlapping syndromes and cannot be phenotyped correctly $[18,36]$. Correct diagnosis is the key to the optimum management. However, our experience showed that HPLC can help in differentiating the two as $\mathrm{HbF}$ and $\mathrm{HbE}$ levels were significantly different in both phenotypes. Also, it is known that regular transfusions in $\mathrm{HbE}$ /beta thalassaemia may decrease $\mathrm{HbF}$ levels but not $\mathrm{HbE}$ [28] which could further assist in correct diagnosis.

We observed a single case of compound heterozygosity for hemoglobin E/S. Hemoglobin $S$ had been reported from this region [23] and the occurrence of this combination was no surprise. However, $\mathrm{HbE}$ and $\mathrm{F}$ levels did not correspond to the previously published reports in the similar condition. We hypothesized that co-existing iron deficiency reduced the quantity of $\mathrm{HbE}$ and high $\mathrm{HbF}$ in sickle cell disorders is not atypical for this geographical region [23].

\section{Strengths and limitations}

This was the first report describing the various $\mathrm{Hb} \mathrm{E}$ phenotypes in Pakistan. The study was limited by patchy clinical details, lack of iron studies and molecular confirmation of $\alpha$ and $\beta$ - thalassaemia. Being a single hospital based study; our data did not reflect the true prevalence of $\mathrm{Hb} \mathrm{E}$ in Pakistani population.

\section{Conclusions}

Various HbE phenotypes are prevalent in Pakistan with $\mathrm{HbEA}$ and $\mathrm{HbE} / \beta$ thalassaemia representing the most common syndromes. Chromatography cannot only successfully identify hemoglobin $\mathrm{E}$ but also assist in further characterization into its phenotype including compound heterozygosity. Definitive diagnosis of $\mathrm{HbE}$ can easily be achieved through RFLP-PCR.

\section{Acknowledgements}

Finances were supported by institutional grant \# SM090-504.

\section{Authors' contributions}

BM conceived of the study, participated in its design and coordination and wrote manuscript. MRH participated in study design, performed chromatography and analysis of the data. AN performed the mutational analysis and wrote part of the manuscript. AR collected the samples, wrote and conceived grant for molecular analysis and helped drafting of manuscript. TM participated in study design, conception and drafting of manuscript. All authors read and approved the final manuscript.

\section{Competing interests}

The authors declare that they have no competing interests.

Received: 27 May 2011 Accepted: 25 March 2012

Published: 25 March 2012

\section{References}

1. Chernoff Al, Minnich V, Chongchareonsuk S: Hemoglobin E, a hereditary abnormality of human hemoglobin. Science 1954, 120(3120):605-606.

2. Chotivanich K, Udomsangpetch R, Pattanapanyasat K, Chierakul W, Simpson J, Looareesuwan S, White N: Hemoglobin E: a balanced polymorphism protective against high parasitemias and thus severe $\mathrm{P}$ falciparum malaria. Blood 2002, 100(4):1172-1176.

3. Weatherall DJ, Clegg JB: Inherited haemoglobin disorders: an increasing global health problem. Bull World Health Organ 2001, 79(8):704-712.

4. Jonxis $\mathrm{JH}$ : Haemoglobinopathies and their occurrence in South East Asia. Paediatr Indones 1975, 15(3-4):112-119.

5. Katsanis E, Luke $\mathrm{KH}, \mathrm{Hsu}$ E, Yates JR: Hemoglobin E: a common hemoglobinopathy among children of Southeast Asian origin. CMAJ 1987, 137(1):39-42.

6. Bain JB: Hemoglobinopathy diagnosis. second edition. London: Blackwell Publishing; 2006

7. Kishore B, Khare P, Gupta RJ, Bisht S, Majumdar K: Hemoglobin E disease in North Indian population: a report of 11 cases. Hematology 2007, 12(4):343-347.

8. Khaleque KA: Haemoglobin $\mathrm{E}$, thalassaemia, and their combination in a Muslim family of East Pakistan. J Trop Med Hyg 1961, 64:171-174.

9. Nguyen CK, Le TT, Duong BT, Dinh PH, Ta TH, Tran HH: Beta-thalassemia/ haemoglobin E disease in Vietnam. J Trop Pediatr 1990, 36(1):43-45.

10. George $E$, Khuziah R: Malays with thalassaemia in West Malaysia. Trop Geogr Med 1984, 36(2):123-125.

11. Lachant NA: Hemoglobin E: an emerging hemoglobinopathy in the United States. Am J Hematol 1987, 25(4):449-462.

12. Fucharoen S, Sanchaisuriya K, Fucharoen G, Panyasai S, Devenish R, Luy L: Interaction of hemoglobin $\mathrm{E}$ and several forms of alpha-thalassemia in Cambodian families. Haematologica 2003, 88(10):1092-1098.

13. Fucharoen G, Fucharoen S, Jetsrisuparb A, Fukumaki Y: Molecular basis of $\mathrm{HbE}$-beta-thalassemia and the origin of $\mathrm{HbE}$ in northeast Thailand: identification of one novel mutation using amplified DNA from buffy coat specimens. Biochem Biophys Res Commun 1990, 170(2):698-704.

14. Vichinsky E: Hemoglobin e syndromes. Hematology Am Soc Hematol Educ Program 2007, 79-83.

15. Fucharoen G, Sanchaisuriya K, Sae-ung N, Dangwibul S, Fucharoen S: A simplified screening strategy for thalassaemia and haemoglobin $E$ in rural communities in south-east Asia. Bull World Health Organ 2004, 82(5):364-372.

16. Joutovsky A, Hadzi-Nesic J, Nardi MA: HPLC retention time as a diagnostic tool for hemoglobin variants and hemoglobinopathies: a study of 60000 samples in a clinical diagnostic laboratory. Clin Chem 2004, 50(10):1736-1747.

17. Wong SC, Aw TC, Suri R, Wong CK, Plaseska D, Efremov GD: Differential diagnosis of $\mathrm{Hb} \mathrm{EE}$ and $\mathrm{Hb} \mathrm{E}$-beta(0)-thalassemia by protein and DNA analyses. Acta Haematol 2000, 103(2):84-89.

18. Sangkitporn S, Sangkitporn SK, Sangnoi A, Duangruang S: Detection of $\mathrm{Hb}$ E mutation (beta(26), GAG-AAG, Glu-Lys) using allelic discrimination analysis. Int J Lab Hematol 2009, 31(1):74-80.

19. Ghani R, Manji MA, Ahmed N: Hemoglobinopathies among five major ethnic groups in Karachi, Pakistan. Southeast Asian J Trop Med Public Health 2002, 33(4):855-861.

20. Rehman Z, Saleem M, Alvi AA, Anwar M, Ahmed PA, Ahmad M: Alphathalassaemia: prevalence and pattern in northern Pakistan. J Pak Med Assoc 1991, 41(10):246-247. 
21. Khattak MF, Saleem M: Prevalence of heterozygous beta-thalassemia in northern areas of Pakistan. J Pak Med Assoc 1992, 42(2):32-34.

22. Ahmed S, Petrou M, Saleem M: Molecular genetics of beta-thalassaemia in Pakistan: a basis for prenatal diagnosis. Br I Haematol 1996, 94(3):476-482.

23. Hashmi NK, Moiz B, Nusrat M, Hashmi MR: Chromatographic analysis of $\mathrm{Hb} \mathrm{S}$ for the diagnosis of various sickle cell disorders in Pakistan. Ann Hematol 2008, 87(8):639-645.

24. Dawod ST, Abulaban M, Kamel K, Huisman TH: Hemoglobin D-beta (0) thalassemia. A case report and family study. Am I Pediatr Hematol Oncol 1988, 10(4):316-318.

25. Moiz B, Hashmi MR, Sadaf S: Performance evaluation of ion exchange and affinity chromatography for $\mathrm{HbA1c}$ estimation in diabetic patients with HbD: a study of 129 samples. Clin Biochem 2008, 41(14-15):1204-1210.

26. Moiz B, Moatter T, Hashmi MR, Hashmi N, Kauser T, Nasir A, Khurshid M: Identification of hemoglobin Q India (alpha 1-64 Asp-His) through ARMS-PCR. First report from Pakistan. Ann Hematol 2008, 87(5):385-389.

27. Khan SN, Butt Fl, Riazuddin S, Galanello R: Hb Sallanches [alpha104(G11) Cys- > Tyr]: a rare alpha2-globin chain variant found in the homozygous state in three members of a Pakistani family. Hemoglobin 2000 24(1):31-35

28. Rees DC, Porter JB, Clegg JB, Weatherall DJ: Why are hemoglobin F levels increased in HbE/beta thalassemia? Blood 1999, 94(9):3199-3204.

29. Shamsi TS: Beta-thalassaemia-a major health problem in Pakistan. J Pak Med Assoc 2004, 54(10):498.

30. Intorasoot STR, Tragoolpua K, Chottayaporn M: Hemoglobin E detection using PCR with confronting two pair primers. J Med Assoc Thai 2008, 9(11):1677-1680

31. Thein SL, Lynch JR, Old JM, Weatherall DJ: Direct detection of haemoglobin E with Mnll. J Med Genet 1987, 24(2):110-111.

32. Rees $D C$, Clegg JB, Weatherall DJ: Is hemoglobin instability important in the interaction between hemoglobin $\mathrm{E}$ and beta thalassemia? Blood 1998, 92(6):2141-2146.

33. Thaver IH, Baig L, Inam ul H, labal R: Anaemia in children: Part II. Should primary health care providers prescribe iron supplements by the observation and presence of assumed symptoms? J Pak Med Assoc 1994, 44(12):284-285.

34. Karim SA, Khurshid M, Memon AM, Jafarey SN: Anaemia in pregnancy-its cause in the underprivileged class of Karachi. J Pak Med Assoc 1994 44(4):90-92.

35. Hamedani P, Hashmi KZ, Manji M: Iron depletion and anaemia: prevalence, consequences, diagnostic and therapeutic implications in a developing Pakistani population. Curr Med Res Opin 1987, 10(7):480-485.

36. Tyagi S, Pati HP, Choudhry VP, Saxena R: Clinico-haematological profile of $\mathrm{HbE}$ syndrome in adults and children. Hematology 2004, 9(1):57-60.

Pre-publication history

The pre-publication history for this paper can be accessed here: http://www.biomedcentral.com/1471-2326/12/3/prepub

doi:10.1186/1471-2326-12-3

Cite this article as: Moiz et al:: Hemoglobin E syndromes in Pakistani population. BMC Blood Disorders 2012 12:3.

\section{Submit your next manuscript to BioMed Central and take full advantage of:}

- Convenient online submission

- Thorough peer review

- No space constraints or color figure charges

- Immediate publication on acceptance

- Inclusion in PubMed, CAS, Scopus and Google Scholar

- Research which is freely available for redistribution

Submit your manuscript at www.biomedcentral.com/submit 